\title{
Cervical Pap smear study and its utility in cancer screening in patients attending out-patient department in a tertiary care hospital
}

\author{
Paridhi Garg, Shweta Mishra*, Pragati Divedi
}

Department of Obstetrics and Gynecology, Rama Medical College Hospital and Research Centre, Hapur, Uttar Pradesh, India

Received: 28 June 2021

Accepted: 26 July 2021

\section{*Correspondence:}

Dr. Shweta Mishra,

E-mail: dr.shwetamishra08@gmail.com

Copyright: ( ) the author(s), publisher and licensee Medip Academy. This is an open-access article distributed under the terms of the Creative Commons Attribution Non-Commercial License, which permits unrestricted non-commercial use, distribution, and reproduction in any medium, provided the original work is properly cited.

\section{ABSTRACT}

Background: Cervical cancer is one of the major causes of mortality among women worldwide. By simple pap screening test cervical cancer and its precursor lesions can be detected and treated early. The aim of the study was to determine and analyze Pap smear reports from women presenting with various gynaecological indications in a tertiary care hospital.

Methods: This retrospective study was conducted in the department of obstetrics and gynaecology at Rama Medical College Hospital and Research Centre, Hapur over a period of 6 months. Patients with various complaints between ages 21 to 70 years were screened during August 2020 to January 2021 by taking Pap smear using Ayres spatula. Total 330 patients were studied. Slides were reported according to the 2014 Bethesda system.

Results: Maximum number of cases were in the age group 31-40 years constituting $32.72 \%$ of the total cases followed by age group 41-50 years. Vaginal discharge was the commonest chief complaint seen in $32.12 \%$ cases followed by menorrhagia. Maximum number of cases reported as non-specific inflammatory smears (64.54\%). Among epithelial cell abnormalities incidence of LSIL was $2.42 \%$ followed by ASCUS (1.82\%).

Conclusions: Pap smear testing is an economical, non-invasive and simple OPD procedure to detect potentially precancerous and cancerous lesions of cervix. It should be established as a routine screening procedure to reduce the treatment burden, morbidity and mortality.

Keywords: Cervical cancer, Screening, Bethesda system, Pap smear

\section{INTRODUCTION}

Cancer of uterine cervix is a leading cause of mortality and morbidity among women world-wide. Cervical cancer is the fourth most common cancer in women. In developing countries, it is the most common gynaecological cancer and one of the leading causes of cancer death among women.

Nearly 4 lacs new cases of cervical cancers are diagnosed annually worldwide and $80 \%$ of them are diagnosed in the developing countries. There are 1.7 million cases in the developing world and as many as 5-13 million women have precancerous lesions. ${ }^{1,3}$ According to National Cancer Registry Program of India, cancers of uterine cervix and breast are leading malignancies seen in Indian women. $^{2}$

Cervical cancers and its precursor lesions can be detected and treated early by using simple Pap screening test. Usually, Pap smear screening test is recommended starting around 21 years of age until the age of 65 years. Can be repeated at three years interval. In case of abnormal Pap smear report, depending on the type of abnormality the test may need to be repeated in six to twelve months. More sensitive and specific investigations like colposcopy guided cervical biopsy etc are needed to diagnose and prevent further progression to cervical cancer. ${ }^{4}$ Pap smear test is performed by opening the vaginal canal with cuscos speculum and collecting cells at the outer opening of the 
cervix i.e.; at the transformation zone, from posterior vaginal wall and endocervical canal. Then the collected cells are examined under a microscope. ${ }^{5}$

The test mainly meant to detect precancerous conditions like cervical intraepithelial neoplasia (CIN) or cervical dysplasia, squamous intraepithelial lesion system (SIL) etc. ${ }^{6}$ In 1988, the Bethesda system of reporting has been introduced to classify the lesions into low- and high-grade intraepithelial lesions. It provides uniform system of terminology which makes management and treatment simple. ${ }^{7}$ The present study was conducted to study the different patterns of cervical lesions in a tertiary care hospital.

\section{METHODS}

This study was a retrospective study conducted in the department of obstetrics and gynaecology of Rama Medical College Hospital and Research Centre, Hapur from August 2020 to January 2021. A total of 330 pap smears were taken from women between ages of 21 to 70 years presenting with different gynaecological complaints and as a routine beyond the age of 45 years by using Ayres spatula. Smears were reported as per the Bethesda system.

\section{Inclusion criteria}

Women between 21 to 70 years of age with sexual history were included.

\section{Exclusion criteria}

Women below 21 years, without sexual exposure, and women above 70 years.

\section{Procedure}

Pap smears were taken by using Ayres spatula. The broad end of spatula was placed on the Cervix and rotated through $360^{\circ}$ and the collected material was spread over a glass slide. The endo-cervical sample was collected using a cyto-brush and was spread over labelled glass slide. All the slides were labelled and immediately transferred to 95\% Ethyl alcohol (transport medium) and sent to pathology department for cytological study. Evaluation was done by cytology using Bethesda Classification. ${ }^{8}$

\section{Specimen adequacy}

It included- (a) satisfactory for evaluation (note presence or absence of endocervical transformation zone component); and (b) unsatisfactory for evaluation

\section{Negative for intraepithelial lesion or malignancy}

\section{Organisms}

Organisms with (a) trichomonas vaginalis; (b) fungal organisms morphologically consistent with Candida species; (c) shift in flora suggestive of bacterial vaginosis; (d) bacteria morphologically consistent with Actinomyces species; and (e) cellular changes consistent with herpes simplex virus.

Other non-neoplastic findings (optional to report, list not comprehensive)

It included- (a) reactive cellular changes associated with inflammation (includes typical repair); (b) radiation; (c) intrauterine contraceptive device; (d) glandular cells status post-hysterectomy; and (e) atrophy.

\section{Epithelial cell abnormalities}

\section{Squamous cells}

It included- (a) atypical squamous cell (ASC); (b) of undetermined significance (ASCUS); (c) cannot exclude high-grade lesion (ASC-H); (d) low-grade squamous intraepithelial lesion (LSIL); (e) high-grade squamous intraepithelial lesion (HSIL); and (f) squamous cell carcinoma.

\section{Glandular cells}

It included- (a) atypical glandular cells (AGC) (specify endocervical, endometrial, or not specified); (b) atypical glandular cells, favour neoplastic (specify endocervical or not specified); (c) endocervical adenocarcinoma in situ (AIS); and (d) adenocarcinoma.

\section{Other (list not comprehensive)}

It included endometrial cells in women 40 years of age or over.

\section{RESULTS}

In our study age of patient, presenting symptoms, reports of cytology were observed and analysed. Table 1 shows that maximum number of cases were in the age group 3140 years constituting $32.72 \%$ of the total cases followed by age group $42-50$ years constituting $26.06 \%$. Minimum percentage $(3.94 \%)$ of cases were $>60$ years of age group.

Table 1: Distribution of cases according to age.

\begin{tabular}{|lll|}
\hline Age group (years) & No. of cases & Percentage (\%) \\
\hline $\mathbf{2 1 - 3 0}$ & 81 & 24.54 \\
\hline $\mathbf{3 1 - 4 0}$ & 108 & 32.72 \\
\hline $\mathbf{4 1 - 5 0}$ & 86 & 26.06 \\
\hline $\mathbf{5 1 - 6 0}$ & 42 & 12.73 \\
\hline $\mathbf{7 6 0}$ & 13 & 3.94 \\
\hline
\end{tabular}

Table 2 depicts vaginal discharge was the commonest chief complaint seen in $44.54 \%$ patients followed by menorrhagia (19.70\%). Out of 330 patients, routine Pap smear was taken in 48 patients $(14.54 \%)$ who were asymptomatic. 
Table 2: Distribution of cases according to symptoms.

\begin{tabular}{|lll|}
\hline Symptoms & No. of cases & $\begin{array}{l}\text { Percentage } \\
(\%)\end{array}$ \\
\hline $\begin{array}{l}\text { Asymptomatic } \\
\text { (routine Pap smear) }\end{array}$ & 48 & 14.54 \\
\hline $\begin{array}{l}\text { Vaginal discharge } \\
\text { Pain in lower } \\
\text { abdomen }\end{array}$ & 147 & 44.54 \\
\hline Post coital bleeding & 12 & 10.9 \\
\hline Menorrhagia & 65 & 3.64 \\
\hline Post-menopausal BPV & 3 & 19.70 \\
\hline $\begin{array}{l}\text { Something coming out } \\
\text { of vagina }\end{array}$ & 19 & 0.9 \\
\hline
\end{tabular}

Table 3 shows maximum number of cases reported as nonspecific inflammatory smears $(64.54 \%)$. Among epithelial cell abnormalities incidence of LSIL and ASCUS was $2.42 \%$ and $1.82 \%$ followed by SCC $(0.91 \%)$.

Table 3: Distribution of cases according to Pap smear report.

\begin{tabular}{|lll|}
\hline PAP smear report & No. of cases & $\begin{array}{l}\text { Percentage } \\
(\%)\end{array}$ \\
\hline Satisfactory & 324 & 98.18 \\
\hline Unsatisfactory & 6 & 1.82 \\
\hline NILM & 305 & 92.42 \\
\hline Trichomonas & 16 & 4.85 \\
\hline Candidiasis & 28 & 8.48 \\
\hline Bacterial vaginosis & 15 & 4.54 \\
\hline Inflammatory & 213 & 64.54 \\
\hline Atrophic & 2 & 0.6 \\
\hline Squamous metaplasis & 31 & 9.39 \\
\hline Epithelial cell & 19 & 5.76 \\
abnormality & 6 & 1.82 \\
\hline ASC-US & 1 & 0.3 \\
\hline ASC-H & 8 & 2.42 \\
\hline LSIL & 1 & 0.3 \\
\hline HSIL & 3 & 0.91 \\
\hline SCC & & \\
\hline
\end{tabular}

\section{DISCUSSION}

With the changes in the life styles and demographic profiles in developing countries, non-communicable diseases are emerging as an important health problem which demand appropriate control program before they assume epidemic propagation. Cancer has been a major cause of morbidity and mortality. Cancer of the cervix is a preventable disorder as the different screening, diagnostic and therapeutic procedures are effective. One of the essential responsibilities of the gynaecologist is to detect neoplasm of the genital tract at the earliest. Since the introduction of cytology into clinical practice by Papanicolaou and Traut in 1944, it has become possible to detect cervical cancer in its pre-invasive stages, thus reducing the morbidity and mortality from this disease.
According to National Cancer Registry Program of India, cancers of uterine cervix and breast are the leading malignancies seen in females of India. There should be an effective mass screening program aimed at specific age group for detecting precancerous condition before they progress to invasive cancers. ${ }^{1,3,9}$ In this study comprising of 330 Pap smear, 324 were satisfactory $(98.18 \%)$ and 6 were unsatisfactory (1.82\%). Unsatisfactory reports can be due to inadequacy of sample, blood stained sample and poor staining.

Table 1 shows distribution of patients according to age. In this study age of patients ranged from 21-69 yrs. Out of 330 patients, maximum number of patients were in the age group 31-40 years comprising $32.72 \%$ followed by 41-50 years comprising $26.06 \%$. $24.54 \%$ were in $21-30$ years, $12.73 \%$ in $51-60$ years and $3.94 \%$ were more than 60 yrs. In study conducted by Sunita et al maximum number of women were between 31 to 40 years age group $(32.68 \%) .{ }^{10}$ In study conducted by Mandakini et al between 15 to 30 years maximum number of women were studied. ${ }^{11}$

Table 2 shows distribution of women according to presenting complaints. Among the 330 women undergoing Pap smear tests, 147 women (44.54\%) presented with chronic white discharge similar to the studies conducted by Verma et al whereas in study conducted by Sachan et al, vaginal discharge was seen in $36.96 \%$ cases and it was $30 \%$ in Lakshmi et al. ${ }^{12-14}$ This was followed by 65 women $(19.70 \%)$, who presented with menorrhagia similar to study by Verma et al $(19.5 \%){ }^{12} 48$ women (14.54\%) underwent Pap smear test as part of routine gynaecological examination. 36 women $(10.90 \%)$ presented with pain in lower abdomen compared to study by Sachan et al $(25.63 \%)$ postmenopausal bleeding was present in 3 patients $(0.9 \%)$ similar to study by Sachan et al (1.45\%) 19 women $(5.76 \%)$ presented with something coming out of vagina and 12 women $(3.64 \%)$ presented with post coital bleeding per vaginum similar to study by Sachan et al $(3.09 \%){ }^{13}$

Table 3 shows distribution of women according to the 2001 Bethesda system Pap smear reports. In our study out of 330 smears, inflammatory smears constituted the maximum bulk of the reporting $(64.54 \%)$ which was almost similar to the study of Lakshmi et al, Sunita et al, Verma et al inflammatory and in study conducted by Mandakini et al inflammatory Pap smear reports were seen in 57.5\%..$^{10,11-14}$ Incidence of Candidiasis and Bacterial vaginosis was $8.48 \%$ and $4.54 \%$ respectively in our study. Sunita et al reported candida in $2.50 \%$ of the total pap smear studied whereas Laxmi et al diagnosed $3 \%$ cases of bacterial vaginosis. ${ }^{10,14}$ Our study demonstrated 19 cases $(5.76 \%)$ of epithelial cell abnormality on cervical cytology out of total 330 cases examined. Out of these cases of epithelial cell abnormality, atypical squamous cells of undetermined significance (ASCUS) and ASCUS-H constituted 1.82\% 
and $0.3 \%$ each of the total cases in the present study which was in concordance with the study conducted by Verma et al and in study conducted by Mandakini et al reports showing ASCUS were 4.1\%.11,12 Incidence of ASCUS was little higher in studies of Sunita et al, Lakshmi et al, Sachan et al and Mandakini et al. ${ }^{10-14}$ In our study LSIL was reported in 8 patients $(2.42 \%)$ out of 330 and HSIL in 1 patient $(0.91 \%)$ which is similar to study conducted by Sunita et al which reported $1.96 \%$ as LSIL and $0.36 \%$ as HSIL. ${ }^{10,11}$ In study conducted by Mandakini et al reports showing LSIL and HSIL were $0.1 \%$ each. Incidence of LSIL and HSIL was higher in studies conducted by Verma et al and Lakshmi et al. ${ }^{12,14}$ 3 case $(0.91 \%)$ of SCC was diagnosed in our study which was in concordance to the findings of Sunita et al and Lakshmi et al carcinoma and in study conducted by Mandakini et al reports showing squamous cell carcinoma were $0.7 \% .^{10,11,14}$ Unsatisfactory for evaluation was reported in 6 cases $(1.82 \%)$ which was similar to the observations made by Verma et al. ${ }^{12}$

\section{CONCLUSION}

Pap smear testing is an economical, non-invasive and simple OPD procedure to detect potentially precancerous and cancerous lesions of cervix. It should be established as a routine screening procedure to reduce the treatment burden, morbidity and mortality. Pap smear tests are inexpensive and affordable by the patients. This procedure doesn't need experts and specialists for collection of smear. Reports in our study like many other studies has shown the importance of Pap smear test in screening cervical cancer. By conducting health camps, increasing health awareness and performing Pap smear screening programmes the incidence of cervical carcinoma can be decreased. ${ }^{15}$

\section{ACKNOWLEDGMENTS}

The authors extend their sincere thanks to the institution and to patient who gave their consent for the inclusion in the study.

\section{Funding: No funding sources Conflict of interest: None declared \\ Ethical approval: Not required}

\section{REFERENCES}

1. Kalkar R, Kulkarni Y. Screening for cervical cancer: an overview. Obstet Gynecol India. 2006;56(2):115-22.
2. National Cancer Regitry Program. Annual Report, 2021. Available at: https://www.ncdirindia.org/ NCRP/AReports.aspx. Accessed on 20 June 2021.

3. Khan MS, Raja FY. Pap smear Screening for Precancerous conditions of the cervical cancers. Pak J Med Res. 2005;44(3):111-3.

4. Mehmetoglu HC, Sadikoglu G, Ozcakir A, Bilgel N. Pap smear screening in the primary health care setting: A study from Turkey. N Am J Med Sci. 2010;2(10):467-72.

5. International Network for Cancer Treatment and Research. A Practical Manual on Visual Screening for Cervical Neoplasia, 2003. Available at: https://screening.iarc.fr/viavilimanual.pdf. Accessed on 20 June 2021.

6. Idestrom M, Milsom I, Ellstrom A. Women's experience of coping with a positive Pap smear: A register-based study of women with two consecutive Pap smears reported as CIN 1. Acta Obstet Gynecol Scand. 2003;82(8):756-61.

7. Pradhan B, Pradhan SB, Mital VP. Correlation of PAP smear findings with clinical findings and cervical biopsy. Kathmandu Univ Med J. 2007;5(4):461-7.

8. Nayar R, Wilbur DC. The Pap test and Bethesda 2014. Cancer Cytopathol. 2015;123(5):271-81.

9. Bishop A, Sherris J, Tsu VD, Brook M. Cervical dysplasia treatment: key issues for developing countries. Bull Pan Am Health Organ. 1996;30(4):378-86.

10. Bamanikar SA, Baravkar DS, Chandanwale SS, Dapkekar P. Study of Cervical Pap smears in a Tertiary Hospital. Indian Med Gazette. 2014;250-4.

11. Patel MM, Pandya AN, Modi J. Cervical Pap smear study and its utility in cancer screening, to specify the strategy for cervical cancer control. National J Community Med. 2011;2(1):49-51.

12. Verma A, Verma S, Vashist S, Attri S, Singhal A. A study on cervical cancer screening in symptomatic women using Pap smear in a tertiary care hospital in rural area of Himachal Pradesh, India. Middle East Fertility Society J. 2017;22:39-42.

13. Sachan PL, Singh M, Patel ML, Sachan R. A Study on Cervical Cancer Screening Using Pap Smear Test and Clinical Correlation. Asia Pac J Oncol Nurs. 2018;5(3):337-41.

14. Lakshmi PV, Gouri SRS. Study and analysis of 200 cervical Pap smears in our hospital. IJCMR. 2016;3:2787-9.

15. Idestrom M, Milsom I, Ellstrom A. Knowledge and attitudes about the Pap-smear screening program: a population-based study of women aged 20-59 years. Acta Obstet Gynecol Scand. 2002;81:962-7.

Cite this article as: Garg P, Mishra S, Divedi P. Cervical Pap smear study and its utility in cancer screening in patients attending out-patient department in a tertiary care hospital. Int J Reprod Contracept Obstet Gynecol 2021;10:3521-4. 